\title{
ZVÝŠENÁ SEISMICKÁ AKTIVITA V EPICENTRÁLNÍ OBLASTI LAŠŤANY (STR̆EDNÍ MORAVA)
}

\author{
Increased seismic activity in the epicentral area Laštany (central Moravia) \\ Josef Havíř, Jana Pazdírková, Zdeňka Sýkorová \\ Ústav fyziky Země, PřF MU, Tvrdého 12, 60200 Brno; e-mail:josef.havir@ipe.muni.cz
}

(14-44 Šternberk, 24-22 Olomouc, 25-11 Hlubočky)

Key words: Bohemian Massif, micro-earthquakes, recent tectonic activity

\begin{abstract}
Weak natural seismic activity is known from the NE part of the Bohemian Massif. More than 200 tectonic events were recorded in this region on the basis of records of seismic stations operated by Institute of Physics of the Earth (IPE) during period 1996-2011. Since 2008 a relatively significant seismic activity has been observed in epicentral area Laštany situated SE of Šternberk. In this area, 221 tectonic events were observed during period September 2008 - December 2011. Local magnitude of strongest event reached value 2.
\end{abstract}

Severovýchodní část Českého masivu se vyznačuje slabými projevy přirozené tektonické aktivity (např. Havír et al. 2006, Kaláb et al. 2007, Špaček et al. 2006). Od roku 1996 do roku 2011 bylo na základě záznamů stanic provozovaných Ústavem fyziky Země PřF MU v Brně (ÚFZ) registrováno více než 2200 přirozených tektonických otřesů s epicentrem v sv. části Českého masivu, lokální magnitudo více než $40 \mathrm{z}$ nich přesáhlo hodnotu 1 (obr. 1).

Většina jevů lokalizovaných v letech 1996 až 2011 do regionu sv. části Českého masivu má velmi nízké hodnoty lokálního magnituda (od -0,5 do 0,5), lokální magnitudo nejsilnějších z těchto tektonických otřesů dosáhlo

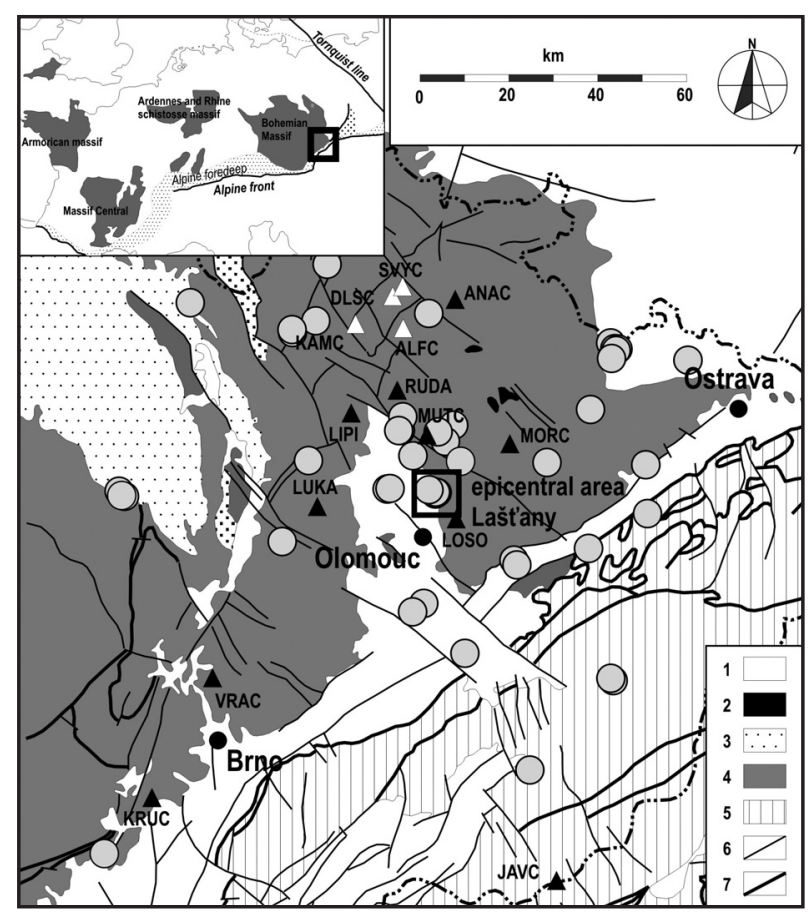

hodnoty 2,2 (obr. 2). Zemětřesení se vyskytují jednotlivě nebo v sekvencích, které mají často charakter seismických rojů. Některé otřesy jsou izolované, většinu však lze přiřadit do různých opakovaně aktivovaných epicentrálních oblastí, např. Hanušovice, Bruntál, Uničov, Dlouhá Loučka, Litovel, Lipník n. Bečvou atd. K nejvýznamnějším epicentrálních oblastem patřila oblast sv. od Šternberka, v blízkosti obce Rýžoviště (Havír 2002). V posledních letech jsou ale projevy seismické aktivity v této epicentrální oblasti velmi nevýrazné. Oproti tomu byla zjištěna vyšší seismická aktivita v epicentrální oblasti jv. od Šternberka, v blízkosti obce Laštany (obr. 1), která se nachází cca $20 \mathrm{~km}$ jjz. od epicentrální oblasti Rýžoviště.

Epicentrum většiny jevů lokalizovaných do epicentrální oblasti Laštany je situováno sz. od obce Bělkovice-Laštany, v těsné blízkosti této obce (obr. 3). Hypocentra se nacházejí převážně v hloubce přibližně $15 \mathrm{~km}$.

Obr. 1: Mapa epicenter přirozených mikrozemětřesení, jejichž lokální magnitudo přesáhlo hodnotu 1 , ve východní části Českého masivu, (období 1996-2011). Vysvětlivky: 1 - neogén; 2 - neovulkanity; 3 - kř́ída pokryvu Českého masivu; 4 - Český masiv (předmesozoické podloží); 5 - prríkrovy Západních Karpat; 6 - hlavní zlomy; 7 - čela př́krovů; šedá kolečka - epicentra mikrozemětřesení; trojúhelníčky - stanice provozované ÚFZ (bíle trojúhelníčky - stanice uzavřené před rokem 2011; černé trojúhelníčky - stanice $\mathrm{v}$ provozu $\mathrm{v}$ roce 2011).

Fig. 1: Map of epicenters of natural micro-earthquakes which local magnitude exceed value 1 in the eastern part of the Bohemian Massif (period 1996-2011). Explanation: 1 - Neogenne; 2 - Cainozoic volcanic rocks; 3 - Cretaceous cover of the Bohemian Massif; 4 - Bohemian massif (pre-Mesozoic basement); 5 - West Carpathian Nappes; 6 - major faults; 7 - front of nappes; gray circles - epicenters of micro-earthquakes; triangles - seismic stations operated by IPE (white triangles - stations closed prior to 2011; black triangles - stations in operation during year 2011). 


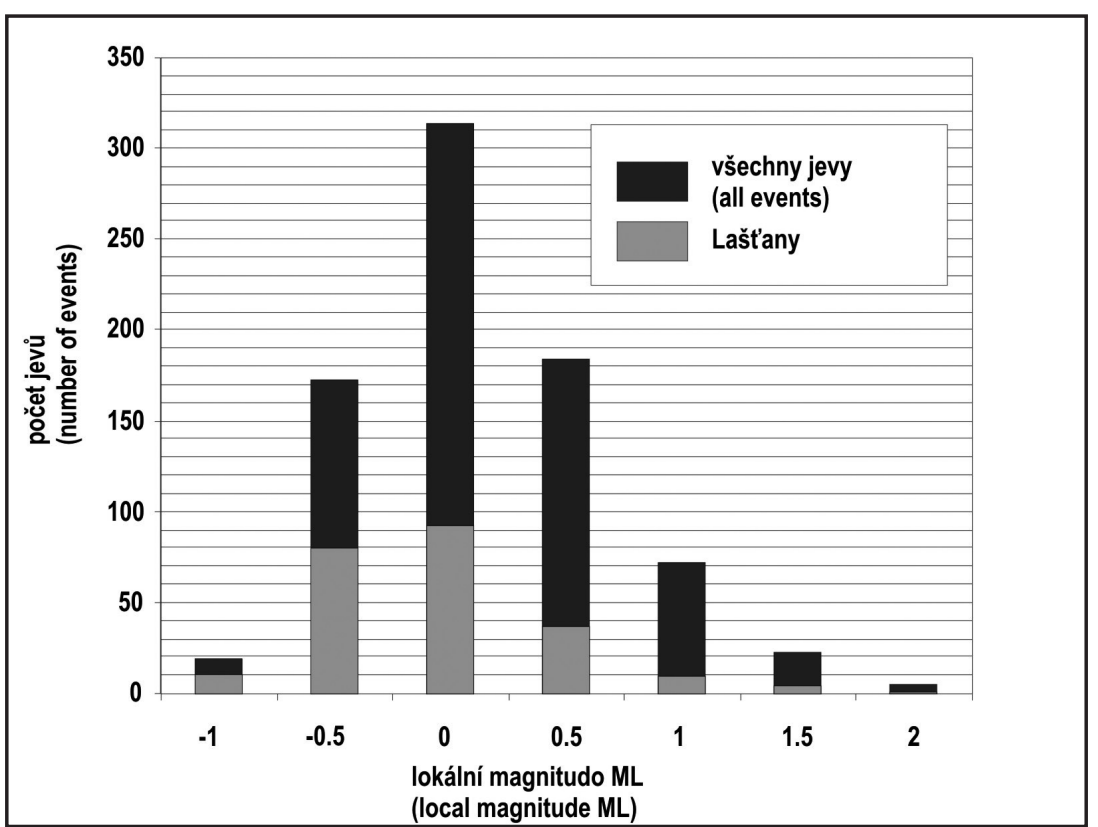

Obr. 2: Histogram počtu všech tektonických otřesů lokalizovaných ve východní části Českého masivu a jevů s epicentrem v epicentrální oblasti Laštany registrovaných v letech 1996 až 2011 v závislosti na jejich lokálním magnitudu.

Fig. 2: Histogram of the number of all micro-earthquakes located in the eastern part of the Bohemian Massif and events situated in the epicentral area Laštany recorded during period 1996-2011 in respect of their local magnitude.

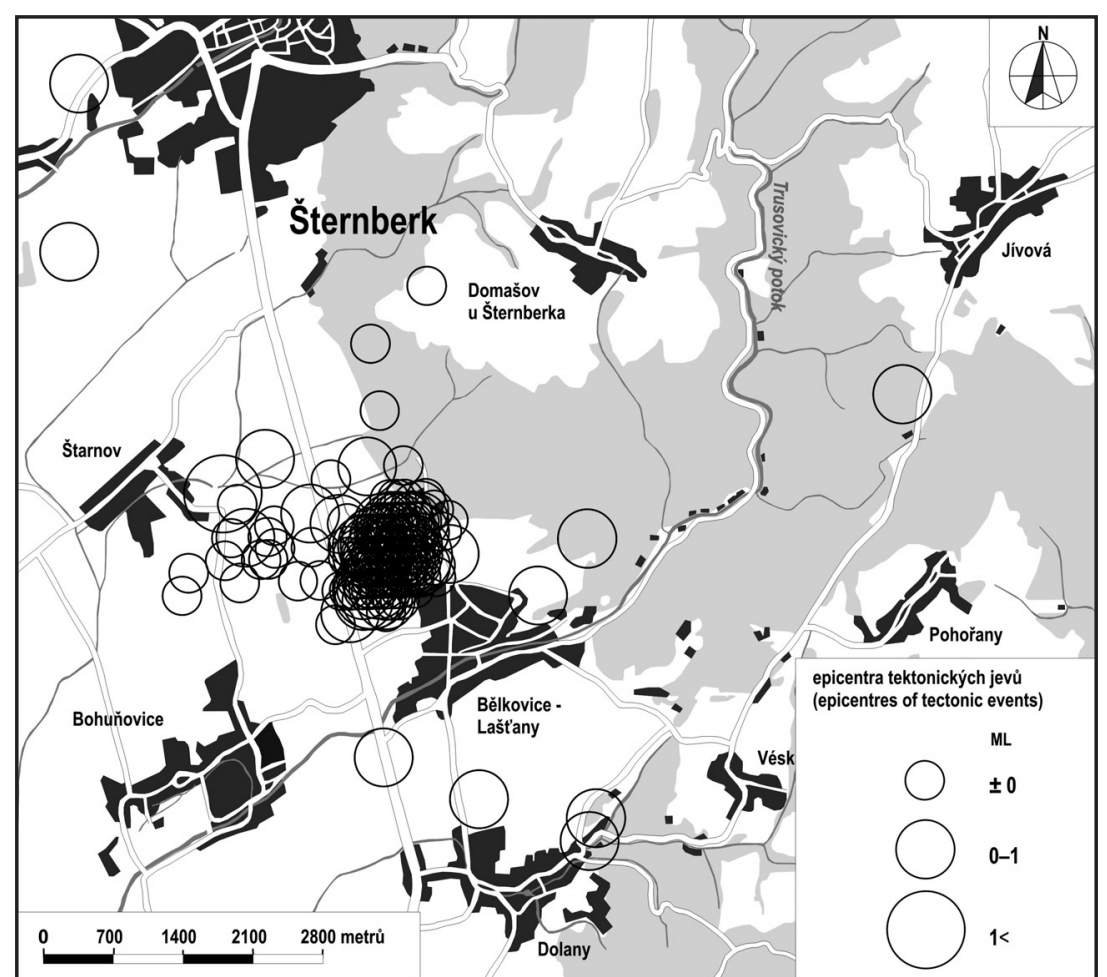

Obr. 3: Mapa epicenter přirozených mikrozemětřesení jv. od Šternberka (epicentrální oblast Laštany), která byla registrována v období 1996-2011.

Fig. 3: Map of natural micro-earthquakes in the region SE of Šternberk (epicentral area Laštany), which were recorded during period 1996-2011.

První výrazný nárůst seismické aktivity v prostoru epicentrální oblasti Laštany byl zaznamenán $\mathrm{v}$ průběhu října 2008 až května 2009, kdy bylo do tohoto prostoru lokalizováno 85 tektonických otřesů a lokální magnitudo nejsilnějšího z nich dosáhlo hodnoty 1,6 (obr. 4). Další oživení seismické aktivity bylo pozorováno $\mathrm{v}$ únoru a březnu 2010 (15 lokalizovaných mikrozemětřesení během dvou měsíců, lokální magnitudo nejsilnějšího otřesu mělo hodnotu 1,0). Nejnovější nárůst seismické aktivity byl pak monitorován $\mathrm{v}$ období od března do srpna 2011. V průběhu tohoto období bylo zaregistrováno 73 tektonických otřesů lokalizovaných do prostoru epicentrální oblasti Laštany, lokální magnitudo nejsilnějšího otřesu dosáhlo hodnoty 2,0 . Tento otřes zaznamenaný dne 19. 4 . 2011 je tak dosud nejsilnějším mikrozemětřesením pozorovaným $\mathrm{v}$ této epicentrální oblasti. Zmíněný otřes byl doprovázen řadou dalších, slabších tektonických jevů. Jen během tří dnů od 17. do 19. dubna 2011 bylo registrováno 11 tektonických otřesů z epicentrální oblasti Laštany, za celý měsíc duben pak bylo v diskutované epicentrální oblasti zjištěno celkem 26 tektonických jevů.

$\mathrm{Na}$ základě nově aplikované korelační analýzy seismických záznamů byla doložena existence 83 velmi slabých (hodnota lokálního magnituda se pohybovala od $-0,9$ do $-1,1$ ) tektonických otřesů u obce Laštany v období 1998 až 2008 (Špaček et al. 2011). Tyto projevy seismické aktivity ale nebylo většinou možné lokalizovat při běžném zpracování dat. Do roku 2008 bylo v epicentrální oblasti Laštany lokalizováno pouze 7 jevů a jejich lokální magnitudo nepřesáhlo hodnotu $0,5, \mathrm{v}$ první polovině roku 2008 zde bylo pozorováno dalších 5 seismických jevů. Oproti tomu od října 2008 bylo v této epicentrální oblasti lokalizováno celkem 221 tektonických otřesů, přičemž u čtyř z těchto 221 otřesů mělo lokální magnitudo hodnotu vyšší než 1 . Nárůst počtu registrovaných a zejména lokalizovaných jevů v epicentrální oblasti Laštany ostře koreluje s dobou uvedení do provozu dvou stanic sítě MONET (stanice LIPI a RUDA, které jsou v provozu od konce roku 2007, viz www-stránky věnované síti MONET: www.ipe.muni.cz/monet). Nabízí se souvislost mezi nárůstem počtu pozorovaných jevů a změnou geometrie sítě seismických stanic provozovaných ÚFZ na severní Moravě. Nelze však pominout, že před rokem 2008 nebyl 


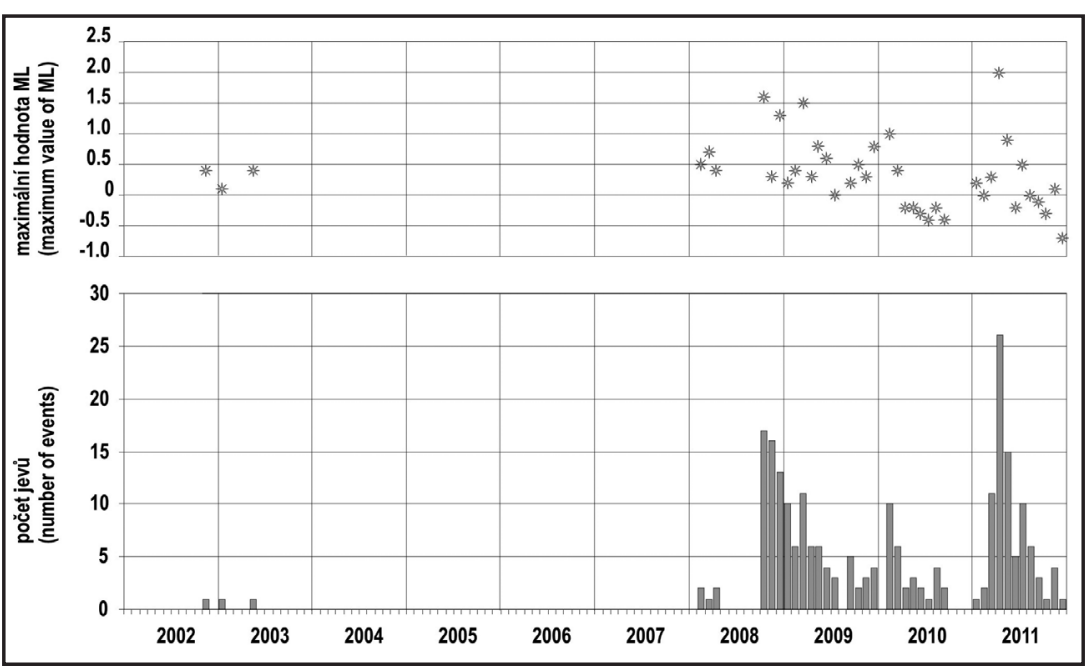

Obr. 4: Počty lokalizovaných tektonických otřesů s epicentry v epicentrální oblasti Laštany registrovaných $\mathrm{v}$ jednotlivých měsících v letech 2002 až 2011 a jejich maximální lokální magnitudo.

Fig. 4: Number and maximum local magnitude of tectonic micro-earthquakes located into epicentral area Laštany recorded during each month in period 2002-2011.

v epicentrální oblasti Laštany zaznamenán žádný tektonický otřes s hodnotou lokálního magnituda 0,5 nebo vyšší. Přitom sít ÚFZ provozovaná na severní Moravě byla schopna spolehlivě zaznamenat takové otřesy i v době, kdy sestávala $\mathrm{z}$ menšího počtu stanic (tj. i v období před rokem 2008). Protože takové jevy (s hodnotou lokálního magnituda 0,5 a vyšší) nebyly do roku 2008 z prostoru epicentrální oblasti Laštany zaznamenány, lze konstatovat, že změna geometrie sítě seismických stanic pravděpodobně není jedinou př́čcinou enormního nárůstu počtu tektonických otřesů lokalizovaných do epicentrální oblasti Laštany od poloviny roku 2008. Nepochybně v této epicentrální oblasti došlo od roku 2008 ke skutečnému nárůstu seismické aktivity.

\section{Poděkování}

Př́spěvek vznikl s finanční podporou projektů CzechGeo/EPOS program č. LM2010008 a ESF/MŠMT projekt CZ.1.07/2.3.00/20.0052 „Výzkumný tým pro ukládání radioaktivních odpadi̊ a jadernou bezpečnost".

\section{Literatura}

Havír, J. (2002): Recent tectonic activity in the area Northwards of Šternberk (Nízký Jeseník Mts.) - present knowledge. - Acta Montana, ser. A, 20, 97-104.

Havíř, J. - Pazdírková, J. - Sýkorová, Z. - Špaček, P. - Švancara, J. (2006): Deset let monitorování přirozené seismicity sv. části Českého masivu stanicemi ÚFZ. - In: Sborník 15. regionální konference „Nové poznatky a měření v seizmologii, inženýrské geofyzice a geotechnice“. Sborník vědeckých prací VŠB-TU Ostrava, řada stavební, 6, 2, 99-106.

Kaláb, Z. - Knejzlík, J. - Holub, K. (2007): Decade of seismological observations in the northern part of Moravo-Silesian region. - Acta Geodynamica et Geomaterialia, 4, 4, 43-49.

Špaček, P. - Sýkorová, Z. - Pazdírková, J. - Švancara, J. - Havír, J. (2006): Present-day seismicity of the south-eastern Elbe Fault System (NE Bohemian Massif). - Studia geophysica et geodaetica, 50, 2, 233-258. Praha.

Špaček, P. - Zacherle, P. - Sýkorová, Z. - Pazdírková, J. (2011): Microseismic multiplets in the northeastern Bohemian Massif. Zeitschrift für Geologische Wissenschaften, Berlin, 39, 5/6, 367-386. 